\title{
Peran Majlis Diba'iyah Dalam Membina Silaturahim Masyarakat Di Kelurahan Paju Kecamatan Ponorogo Kabupaten Ponorogo
}

\author{
Murdifin \\ Institut Agama Islam Sunan Giri Ponorogo \\ murdifin34@gmail.com
}

Agus Setyawan

IAI Sunan Giri Ponorogo

setyawanagus@gmail.com

\begin{abstract}
Abstrak
Silaturahim dalam kegiatan diba'iyah ini dimaksudkan untuk menjaga keharmonisan hubungan masyarakat dalam bentuk kekerabatan, tetangga, maupun persaudaraan, bahkan turut pula membawa efek yang sangat positif bagi pribadi orang yang melakukannya. Silaturrahim merupakan salah satu perwujudan dari pada perintah ajaran agama islam yaitu "hablum minannass" menjalin hubungan horisontal dengan sesama manusia. Untuk mengungkapkan hal tersebut peneliti menggunakan pendekatan kualitatif. Sedangkan pada metode pengumpulan data, peneliti menggunakan metode wawancara, observasi, dan dokumentasi. Kemudian, metode analisis datanya menggunakan konsep dari Miles dan Huberman yaitu reduksi data, penyajian data, dan penarikan kesimpulan. Dari hasil penelitian ditemukan bahwa: 1) Adanya kegiatan diba'iyah ini dapat menambah jalinan silaturahim warga Kelurahan Paju semakin erat, hal ini dikarenakan dengan diadakannya kegiatan diba'iyah masyarakat meluangkan waktu untuk berkumpul dengan tetangganya sehingga terjalinlah komunikasi yang erat antar warga. Mereka saling menyapa, saling berjabatangan ketika baru datang maupun ketika mau pulang dari kegiatan diba'iyah, 2) Kendala dalam melaksanakan dib'an di Kelurahan Paju yaitu: kurangnya minat dari warga sehingga kegiatan dib'iyah tidak bisa berjalan dengan rutin, selain itu dengan minimnya generasi penerus yang bisa vokal sehingga kegiatan diba'iyah sulit berjalan pada setiap minggunya. Kurangnya dukungan dari sesepuh untuk pembinaan generasi muda sehingga lambat laun kegiatan diba'iyah bisa pudar. Hal lain yang menjadi kendala adalah alat untuk mengiringi dibaiyah seperti kompang dan lainyya sangat kurang, ada namun sudah tak layak pakai lagi.
\end{abstract}

\section{Kata Kunci: Dibaiyah, Silaturrahim, Masyarakat}

\begin{abstract}
Gathering in this diba'iyah activity is intended to maintain harmonious community relations in the form of kinship, neighbors, and brotherhood, even contributing to a very positive effect on the person who does it. Silaturrahim is one of the manifestations of the commandments of Islamic teachings, namely "hablum minannass" to establish horizontal relationships with fellow humans. To reveal this, researchers used a qualitative approach. Whereas in the data collection method, researchers used interview, observation, and documentation methods. Then, the data analysis method uses the concept of Miles and Huberman, namely data reduction, data presentation, and
\end{abstract}


drawing conclusions. From the results of the research it was found that: 1) The existence of this diba'iyah activity can increase the relationship between the residents of Paju Village, this is because with the holding of activities in the community, people take the time to gather with their neighbors so that close communication between residents is established. They greet each other, shake each other when they just arrive or when they want to come home from the diba'iyah activities, 2) Obstacles in carrying out pemb'an in Paju Village, namely: lack of interest from residents so that activities cannot run regularly, besides the lack of future generations who can be vocal so that diba'iyah activities are difficult to run on a weekly basis. Lack of support from elders for fostering the younger generation so that gradually diba'iyah activities can fade. Another thing that becomes an obstacle is that the tools to accompany the training, such as Kompang and others, are very lacking, but they are no longer suitable for use.

Keywords: Dibaiyah, Silaturrahim, Society

\section{Pendahuluan}

Manusia adalah mahluk sosial, ia tidak bisa hidup dan berkembang tanpa adanya bantuan dari orang lain. Maksudnya dalam kehidupan bermasyarakat ia tidak dapat survive jika tidak berinteraksi dengan manusia lainnya. Ada berbagai wadah yang tersedia untuk melakukan interaksi tersebut, salah satunya yakni majlis diba'. Diba'an, atau biasa dikatakan Maulid Diba adalah tradisi membaca atau melantunkan shalawat kepada Nabi Muhammad yang dilakukan oleh masyarakat yang kebanyakan warga NU. Pembacaaan shalawat diba' biasanya dilakukan bersama secara bergantian.Ada bagian dibaca biasa, namun pada bagian-bagian lain lebih banyak menggunakan lagu.Istilah diba'an mengacu pada kitab berisi syair pujian karya al-Imam al-Jaliil as-Sayyid as-Syaikh Abu Muhammad Abdurrahman ad-Diba'iy asy-Syaibani az-Zubaidi alHasaniy.Biasanya, selain manual juga menggunakan iringan musik seperti terbang dan alat tradisional lainnya.

Adanya majlis diba' ditengah-tengah masyarakat bertujuan untuk menambah ilmu dan keyakinan agama yang akan mendorong pengalaman ajaran agama sebagai ajang silaturahmi anggota masyarakat dan untuk meningkatkan kesadaran dan kesejahteraan rumah tangga dan lingkungan jamaahnya. Masih dalam konteks yang sama, majlis ini juga berguna untuk membina dan mengembangkan kehidupan beragama dalam rangka membentuk masyarakat yang bertakwa kepada Allah SWT, menjadi ajang silaturrahim antara sesama muslim.

Hal lain yang menjadikan agama menunjukan peran fungsionalnya adalahketika agama memberikan perubahan pada komunitas itu dan memberikan warna baru dalam masyarakat. Keyakinan akan kebenaran ajaran agama akan mendorong manusia sebagai elemen pokok dalam masyarakat akan bersikap sesuai ajarannya. Tentu hal ini juga akan 
mempengaruhi pandangan hidup dan budayanya, yang akan terekspresi dalam laku kehidupannya (SahFutra, 2019).

Dalam abad ini informasi dakwah harus bisa maksimal. Karena dakwah mempunyai peran dan fungsi penting dalam penyebaran agama islam. Dengan kelebihan yang dimiliki oleh islam sebagai wasilah (media) dakwah, tidak menutup kemungkinan masyarakat lebih memilih media ini. Dakwah adalah suatu proses upaya mengubah pada suatu situasi pada situasi yang lain yang lebih baik sesuai ajaran islam. Atau proses menunjukan manusia ke jalan Allah yaitu AlIslam yang tersusun secara sistematis dan logis.

Sistematis artinya urutan-urutannya tersususun dari tingkat paling bawah hingga tingkat paling atas, ataupun sebaliknya. Logis artinya sesuai dengan jalan pikiran manusia ahli pikir atau ahli logika bagi seorang Da'i sudah barang tentu memiliki tujuan yang ingin dicapainya dan seorang Da'i haruslah efektif dan efisien dalam mengorganisir unsur dakwah secara baik dan tepat, salah satu komponennya iyalah media dakwah.

Pemanfaatan Diba'iyah adalah sebagai salah satu media dakwa karena kapada zaman dahulu orang tua kita merupakan media yang sangat populer di tengah masyarakat yang ada di setiap kelompok. Pengajian, yasinan, mushola, masjid dan lain-lain. Oleh karena itu setiap apa yang disampaikan lewat diba' akan sangat mudah sampai ketengah kalangan masyarakat.

Dalam melakukan komunikasi dengan dakwah, tentunya diperlukan sebuah media dan sarana guna menjembatani proses itu agar berhasil dan membawa pengaruh yang positif, salah satunya dengan metode diba'iyah atau berjanji. Berdakwah melalui diba'iyah atau berjanji merupakan sarana yang tepat untuk menyampaikan pesan dakwah. Sekarang banyak bermunculan para tokoh agama yang menyampaikan dakwahnya melalui diba' atau berjanji.

Diba'an merupakan salah satu kesenian yang digarap dengan tujuan untuk memberikan wawasan dan pendidikan kepada masyarakat mengenai riwayat Nabi Muhammad saw, di samping itu juga memberikan hiburan kepada masyarakat sekitar. Kesenian yang berdiri pada tahun 1988 ini pada awalnya tidak terlepas dari seorang tokoh Islam yang yang telah lulus dari pondok. Kesenian Diba'an merupakan kesenian yang masih dapat bertahan di arus kemodernan. Bentuk dari kesenian ini adalah perpaduan seni musik, seni tari, dan seni suara. Syair yang dipakai adalah bacaan Diba'. Diba' adalah sejarah NabiMuhammad dari ia lahir hingga meninggal dunia. Musik yang dipakai adalah musik Jawa modern yang sering kita kenal dengan campursari. Kesenian ini memakai instrumen yakni terbang dan syair yang dinyanyikan secara 
serentak dan ada salah satu syair yang dinyanyikan secara bersaut-sautan serta diikuti dengan gerakan yang dinamis sehingga kesenian ini sangat menarik perhatian masyarakat.

Melaksanakan tugas dakwah islamiyah merupakan aktifitas dakwah dalam membina silaturahim masyarakat Kelurahan Paju khususnya bagi para ibu. Ditengah kesibukan ibu-ibu bekerja dan mengurus rumah tangga setidaknya memiliki waktu luang. Saat itulah kegiatan rutin diba'iyah dapat dimanfaatkan untuk berkumpul para ibu dalam suatu wadah agar memudahkan dalam bersilaturrahmi. Silaturahim dalam kegiatan diba'iyah ini dimaksudkan untuk menjaga keharmonisan hubungan masyarakat dalam bentuk kekerabatan, tetangga, maupun persaudaraan, bahkan turut pula membawa efek yang sangat positif bagi pribadi orang yang melakukannya. Silaturrahim merupakan salah satu perwujudan dari pada perintah ajaran agama islam yaitu "hablum minannass” menjalin hubungan horisontal dengan sesama manusia.

Hubungan yang harmonis dalam kehidupan bermasyarakat dapat terjadi apabila silaturrahim dapat terjalin dengan baik, oleh karena itu hubungan yang harmonis lebih ditekankan lagi terhadap keluarga, kemudian tetangga dan sahabat, serta anggota masyarakat lainnya.Islam menghendaki hubungan kasih saying, karena dapat membina persaudaraan dan dapat mewujudkan persatuan dan menghilangkan permusuhan.Silaturrahim juga dianggap sebagai salah satu kebutuhan pokok yang tidak boleh diabaikan.

Dari uraian diatas dapat dipahami bahwa betapa pentingnya informasi melalui diba' yang bernuansa islami. Maka harus tersebar luas dalam menyampaikan kebenaran tersebut merupakan tanggung jawab islam secara keseluruhan. Sesuai dengan misinya sebagai "Rahmatan Lil'alamin" harus di sampaikan dengan wajah yang menarik agama supaya umat lain beranggapan bahwa kehadiran islam bukan sebaga ancaman bagi mereka melainkan kedamaian dan ketentraman dalam kehidupan mereka sekaligus sebagai pengantar menuju kebahagiaan kehidupan dunia dan akhirat.

\section{Metode Penelitian}

Metode penelitian atau metode riset berasal dari bahasa inggris. Metode berasal dari kata Method, yang berarti ilmu yang menerangkan cara-cara yang ditempuh untuk mencapai suatu tujuan. Kata penelitian merupakan terjemahan dari bahasa inggris " research" yang terdiri dari kata re mengulang dan search ( pencarian, pengejaran, penelusuran, dan penyelidikan). Maka research berarti melakukan pencarian, sehingga langkah logis dan sistematis tentang pencarian 
yang berkenaan dengan masalah tertentu untuk diolah, dianalisa, diambil kesimpulan dan selanjutnya dicarikan pemecahannya 9Bahtiar, 1999).

Menurut kamus Webster's New Inernational, yang dikutip oleh Muhammad Nazir penelitian adalah penyelidikan yang hati-hati dan kritis dalam mencari fakta dan prinsip-prinsip suatu penyelidikan yang amat cerdik untuk menetapkan sesuatu (Nazir, 1998). Dalam suatu penelitian karya ilmiah, terlebih dahulu perlu dipahami metodologi penelitian. Metodologi penelitian yang dimaksud merupakan seperangkat pengetahuan tentang langkah-langkah sistematis dan logis, tentang pencarian data yang berkenaan dengan masalah-masalah tertentu. Penelitian adalah suatu metode studi yang dilakukan seseorang melalui penyelidikan yang hatihati terhadap suatu masalah, sehingga diperoleh pemecahan yang tepat pada masalah tersebut (Suprayogo, 1998). dalam melakukan penelitian untuk memperoleh fakta yang dipercaya kebenarannya, maka metode penelitian itu penting artinya karena penelitian dapat dinilai valid tidaknya itu berdasarkan ketepatan penggunaan metode penelitiannya.

Metode yang digunakan dalam penelitian ini merupakan metode kualitatif. Menurut godgan dan guba pendekatan kualitatif adalah prosedur penelitian yang menghasilkan data deskriptif ( data yang dikumpulkan berupa kata-kata, gambar, dan bukan angka) (Moleong,2006). Sedangkan menurut kirk dan Miller penelitian kualitatif merupakan tradisi tertentu dalam ilmu pengetahuan social yang secara fundamental bergantung pada pengamatan terhadap manusia dalam kawasannya sendiri dan berhubungan dengan orang lain dalam bahasa istilahnya.

\section{Hasil Penelitian dan Pembahasan}

\section{Pesan dakwah}

a. Pengertian pesan dakwah

Pesan adalah sesuatu yang disampaikan pengirim kepada komunikan. Pesan merupakan isyarat atau symbol yang disampaikan oleh seseorang untuk salurantertentu dengan harapan bahwa pesan itu akan mebgutarakan atau menimbulkan suatu makna tertentu dalam diri orang lain yang hendak diajak berkomunikasi (Cangara, 1998). Menurut Widjaja, pesan adalah keseluruhan dari pada apa yang disampaikan oleh komunikator. Pesan seharusnya mempunyai inti pesan (tema) sebagai pengarah didalam usaha mencoba mengubah sikap dan tingkah laku 
komunikasi. Pesan dapat disampaikan secara panjang lebar, namun yang perlu diperhatikan dan diarahkan kepada tujuan akhir darti komunikasi(Widjaja, 1996).

Sementara Susanto Astrid mengatakan bahwa pesan adalah ide, gagasan, informasi, dan opini yang dilontarkan seseorang komunikator kepada komunikan yang bertujuan untuk mempengaruhi komunikan kearah sikap yang diinginkan oleh komunikator (Astrid, 1997). Menyampaikan pesan tidak hanya melalui pesan verbal saja, seperti yang telah dijelaskan oleh Astrid, namun kita juga dapat menyampaikan pesan melalui komunikasi nin verbal. Komunikasi non verbal yaitu proses komunikasi dimana pesan disampaikan tidak menggunakan kata-kata seperti bahasa tubuh, ekspresi wajah, kontak mata, sentuhan, dan lain sebagainya. Adapun bentuk-bentuk komunikasi non verbal dibagi menjadi 7 macam yaitu.

1) Komunikasi Visual

Komunikasi visual merupakan salah satu bentuk komunikasi yang digunakan untuk menyampaikan pesan berupa gambar-gambar, grafik-grafik, lamban-lambang, atau simbulsimbul.Dengan demikian menggunakan gambar-gambar yang relevan, dan penggunaan warna yang tepat, serta bentuk yang unik akan membantu mendapat perhatian pendengar. Disbanding hanya mengucapkan kata-kata saja, penggunaan komunikasi visual ini akan lebih cepat dalam memproses informasi kepada para pendengar.

2) Komunikasi Sentuhan

Ilmu yang mempelajari tentang sentuha dalam komunikasi non verbal sering disebut haptik. Sebagai contoh : bersalaman, pukulan/menepuk bahu, mengelus-ngelus, sentuhan di punggung dan lain sebagainya merupakan salah satu bentuk komunikasi yang menyampaikan suatu maksud/tujuan tertentu dari orang yang menyentuhnya.

3) Komunikasi Gerakan Tubuh

Gerakan tubuh merupakan bentuk komunikasi non verbal, seperti melakukan kontak mata, ekspresi wajah, isyarat dan sikap tubuh.Gerakan tubuh digunakan untuk menggantikan suatu kata yang diucapkan.Dengan gerakan tubuh, seseorang dapat mengetahui informasi yang disampaikan tanpa harus mengucapkan suatu kata.Seperti menganggukan kepala berarti setuju.

4) Komunikasi Lingkungan 
Lingkungan dapat memiliki pesan tertentu bagi orang yang melihat atau merasakannya.Contoh: jarak, ruang, temperature dan warna. Ketika sesorang menyebutkan bahwa "jaraknya sangat jauh"، ruangan ini kotor", "lingkungan panas”, dan lain-lain berarti seseorang tersebut menyatakan demikian karna atas dasar penglihatan dan oerasaan kepada lingkungan tersebut.

5) Komunikasi Penciuman

Komunikasi penciuman merupakan salah satu bentuk komunikasi suatu pesan/informasi melalui aroma yang dapat di hirup oleh indera penciuman. Misalnya aroma parfum bugari, seseorang tidak akan memahami bahwa parfum tersebut bulgari apabila ia hanya menciumnya sekali.

6) Komunikasi Penampikan

Seseorang yang memakai pakaian yang rapi atau dapat dikatakan penapilan menarik, sehingga mencerminkan kepribadiannya.Hal ini merupakan bentuk komunikasi yang menyampaikan pesan kepada orang yang melihatnya. Tetapi orang yang akan menerima pesan berupa tanggapan yang negatif apabila penampilanya buruk (pakaiannya tidak rapi, kptor, dan lain-lain).

\section{7) Komunikasi Cita Rasa}

Komunikasi citra rasa merupakan salah satu bentuk komunikasi, dimana komunikasi penyampaian suatu pesan atau informasi melalui cita rasa dari suatu makanan atau minuman. Seseorang tidak akan mengatakan bahwa suatu makanan atau minuman memiliki rasa enak, manis, lezat dan lain-lain, apabila makanan tersebut telah memakan atau meminumnya. Sehingga dapat dikatakan bahwa citarasa dari makanan atau minuman tadi menyampaikan suatu maksud atau makna.Dalam Al-Qur'an juga sering kita jumpai atau digunakan untuk berdakwah. Allah SWT berfirman:

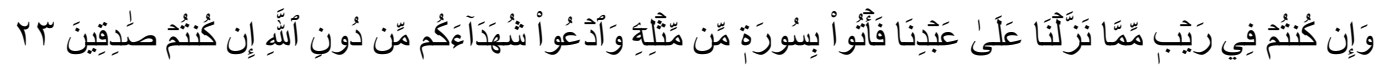

Artinya: Dan jika kamu (tetap) dalam keraguan tentang Al-Qur'an yang kami wahyukan kepada hamba kami ( Muhammad), buatlah suatu surat saja yang 
semisal Al-Qur'an itu dan ajaklah penolong-penolongmu selain Allah, Jika kamu orang-orang yang benar.( QS. Al baqarah ayat 23)

Menurut Ali Yafi sifat dasar dakwah meliputi: (Yafi, 1992)

1. Ajakan ke Darussalam ( Mahligai keda,aian abadi)

2. Ajakan kepada pembebasan (magfiroh)

3. Menyebarkan rahmat dan kasih sayang sebagai citra utama dakwah

4. Menggunakan pendekatan edukatif, persuasif, dan bertahap.

5. Secara umum para pendakwah atau da'i ini sering disebut dengan sebutan mubaligh, namun sebutan ini konotasinya sangat sempit, karena masyarakat cenderung mengartikannya sebagai orang yang menyampaikan ajaran islam melalui lisan, seperti penceramah, khotib, dan sebagainya. Secara lebih luas Da'i diartikan sebagai orang melaksanakan dakwah baik lesan, tulisan, maupun perbuatan yang dilakukan secara individu, kelompok, atau lewat organisasi atau lembaga-lembaga (Munir, 2006).

\section{b. Jenis Pesan Dakwah}

Berdasarkan sumbernya, pesan dakwah pada garis depannya terbagi menjadi 2, yaitu : pesan utama ( Al-Quran dan Hadist) dan pesan tambahan atau penunjang (selain Al- Qur'an dan Hadist) adapun secara luas, pesan dakwah bersumer dari, ayat-ayat Al-Qur'an, Hadis Nabi SAW, pendapat para sahabat Rasul, pendapat para Ulama, hasil penelitian ilmiyah, kisah, berita dan oeristiwa, karya sastra, karya seni, termasuk pengalaman seseorang dan sebagainya.

Pada saat dakwah mulai sulit untuk dicerna, maka kita berupaya untuk memudahkannya. Pada saat banyak orang yang kurang antusias dan kurang yakin terhadap peran dakwah, maka kita mencari keterangan-keterangan yang menguatkan organisasi tersebut, atau bukti-bukti nyata dalam kehidupan. Salah satunya adalah melalui pengalaman seseorang atau pribadi yang terkait dengan tema atau topik dakwah tersebut. Selain itu berdakwah juga dapat melalui syair-syair, lagu, film, bahkan tarian. Karena dunia dakwah semakin luas di era globalisasi ini kita tetap harus mempertahankan metode dakwah klasik yaitu melalui dibaiyah, selain untuk melestarikan budaya metode dakwah ini bisa di terima masyarakat-masyarakat, yang khususnya bertempat tinggal di daerah pedesaan atau pinggiran kota, dengan melantunkan syair-syair yang terdapat pada buku dibaiyah, dapat memberikan kententraman batin sehingga para masyarakat yang 
mengikuti kegiatan dibaiyah dapat terinspirasi dan merasa nyaman dalam menerima pesan-pesan dakwah yang terkandung didalamnya.

\section{Komponen Dakwah melalui Dibaiyah}

a. Wasilah (Media Dakwah)

Agama mengandung ajaran-ajaran yang cenderung dogmatis dan absolut,sehingga agama tidak bisamenerima hal baru, bahkan cenderung menentang pembaharuan. Lain halnya dengan kebudayaan, yang merupakan hasil kreasi manusia yang lahir dari persentuhan pemikiran akal dengan kenyataan hidup,maka ia selalu mengalami perubahan dan memiliki sifat dinamis.Oleh karena itu, tidak mengherankan bila antara agama dan perkembangan kebudayaan terdapatkesenjangandan disharmonisasi. Menurut Harun Nasution, masyarakat yang terlalu kuat memegang agamanya, maka kebudayaan yang ada di tengah-tengah masyarakat akan sulit berkembang dengan baik (Misbahuddin, 2018).

Adalah alat yang dipergunakan untuk menyampaikan materi dakwah atau ajaran islam kepada mad'u. Menurut hamzah yaqub wasilah dibagi menjadi lima yaitu: lisan, tulisan, lukisan, audio visual, dan akhlak:

1. Lisan, inilah media dakwah yang paling sederhana yang menggunakan lidah dan suara.

2. Tulisan, bisa berupa buku, majalah, surat kabar, surat menyurat (Korespondensi), spanduk, flah-card,dan sebagainya.

3. Lukisan, gambar, karikatur, dan sebagainya.

4. Audio visual, yaitu alat dakwah yang merangsang indera pendengaran atau penglihatan dan kedua-duanya, seperti televisi, film, CD internet dan sebagainya.

5. Akhlak, yaitu perbuatan-perbuatan nyata yang mencerminkan islam dapat dinikmati serta didengarkan oleh Mad'u.Dari segi penyampaian dakwah.

Moh. Ali Aziz dalam bukunya Ilmu Dakwah terbagi menjadi 3 golongan:

a) The Spoken Words (yang berbentuk ucapan) 
Yang termasuk kategori ini adalah alat yang dapat mengeluarkan bunyi. Karena hanya dapat di tangkap oleh telinga dan bisa dipergunakan sehari-hari, seperti telepon, radio, dan sejenisnya yang termasuk dalam bentuk ini.

b) The Printed Writting (yang berbentuk tulisan)

Yang termasuk didalamnya adalah barang-barang tercetak, gambar-gambar tercetak, lukisan-lukisan, buku, surat kabar, majalah, brosur, pamplet, dan sebagainya.

c) The Audio Visual ( yang berbentuk gambaran hidup)

Yaitu merupakan penggabungan dari golongan diatas yaitu termasuk golongan ini adalah film, televisi, vidio dan sebagainya (Aziz, 2004). Ditengah- tengah perkembangan tekhnologi yang semakin canggih, dakwah melalui dibaiyah dapat di padukan dengan alunan musik kontemporer seperti alat-alat hadroh kontemporer, bahkan piano atau keyboard, untuk menambah semangat masyarakat dalam melantunkan sholawat. Serta memberikan pengalaman baru untuk masyarakat.

\section{b. Pengruh atau Efek}

Setiap aksi dakwah akan menimbulkan reaksi. Efek atau unsur itu sendiri sebenarnya berasal dari bahasa arab yang berarti bekasan, sisa, atau tanda. Efek (atsar) sering disebut dengan feed back(umpan balik) dari proses dakwah ini seringkali dilupakan atau tidak banyak menjadi perhatian para da'i. Kebanyakan mereka menggap bahwa setelah dakwah disampaikan maka selesailah dakwah tersebut. Padahal efek sangat besar, artinya dalam penentuan langkah-langkah dakwah berikutnya. Tanpa menganalisis atsar dakwah maka kemungkinan kesalalahan strategi yang sangat merugikan pencapaian tujuan dakwah akan terulang kembali. Sebaliknya dengan menganalisis atsar dakwah secara cermat dan tepat, maka kesalahan kesalahan strategi dakwah akan segera diketahui untuk didakan penyempurnaan pada langkah-langkah berikutnya (corrective action).

Sebagaimana diketahui bahwa dalam upaya mencapai tujuan dakwah maka kegiatan dakwah selalu diarahkan untuk mempengaruhi tiga aspek perubahan diri obyeknya, yakni perubahan pada aspek pengetahuannya (knolage), aspek sikapnya (attitude), dan aspek perilakunya (behevioral).

\section{1) Efek Kognitif}


Setelah menerima pesan dakwah, mitra dakwah menyerap isi dakwah tersebut melalui proses berfikir, dan efek kognitif ini bisa terjadi apabila perubahan pada apa yang diketahui, dipahami, dan dimengerti oleh mad'u tentang isi pesan yang diterimanya.

\section{2) Efek Afektif}

Efek ini merupakan pengaruh dakwah berupa perubahan sikap mad'u setelah menerima pesan. Sikap adalah sama dengan proses belajar dengan tiga variable sebagai penunjangnya yaitu perhatian, pengertian dan penerimaan.

3) Efek behaviora

Efek ini merupakan suatu bentuk efek dakwah yang berkenaan dengan pola tingkah laku mitra dakwah ata mad'u dalam merealisasikan materi dakwah yang telah diterima dalam kehidupan sehari-hari.

\section{Dibaiyah sebagai Media Dakwah}

\section{a. Pengertian Dibaiyah}

Diba'an, atau biasa dikatakan Maulid Diba adalah tradisi membaca atau melantunkan shalawat kepada Nabi Muhammad yang dilakukan oleh masyarakat yang kebanayakan warga NU.Pembacaaan shalawat dilakukan bersama secara bergantian. Ada bagian dibaca biasa, namun pada bagian-bagian lain lebih banyak menggunakan lagu.Istilah diba'an mengacu pada kitab berisi syair pujian karya al-Imam al-Jaliil as-Sayyid as-Syaikh Abu Muhammad Abdurrahman ad-Diba'iy asy-Syaibani az-Zubaidi al-Hasaniy.Biasanya, selain manual juga menggunakan iringan musik seperti terbang dan alat tradisional lainnya.

b. Kelebihan dan Kekurangan dibaiyah/ Barzanjy

Kelbihan dari dibaiyah iyalah terdapat nilai-nilai positif diantaranya:

1) Nilai Religius

Pembacaan kitab Al-Barzanji merupakan bentuk bukti kecintaan penganut agama Islam terhadap Nabi Muhammad. Syair dan hikayat yang tertulis dalam kitab tersebut memaparkan nilai-nilai yang baik yang dapat meningkatkan kadar religiusitas seseorang. Selain itu, masyarakat juga dapat mengambil hikmah dari kehidupan Nabi Muhammad seperti yang dibacakan dalam kitab tersebut.

2) Nilai Sosial 
Tradisi barzanji yang digelar pada perayaan hari besar Maulid Nabi dan dalam berbagai upacara lainnya di masyarakat, seperti perkawinan, kelahiran anak, khitanan, dan lain-lain. Kegiatan tradisi ini merupakan ruang bagi masyarakat untuk bersosialisasi antara satu dengan yang lain. Kegiatan barzanji mempertemukan mereka yang jarang bertemu, sehingga akan mempererat tali persaudaraan dan ikatan sosial dalam masyarakat.

3) Nilai Budaya

Syair-syair yang terangkum dalam kitab Barzanji, meskipun menceritakan kehidupan Nabi Muhammad, merupakan karya yang bernilai sastra tinggi. Sebagaimana yang kita ketahui, bangsa Arab mempunyai tradisi penulisan sastra.

Diantara kelebihan yang tertera diatas, terdapat juga kekuraannya yang sangat signifikan yaitu berkurangnya minat masyarat terhadap dibaiyah/berzanjy sehingga membutuhkan pengertian lebih serta ajakkan yang dapat menambah minat masyarakat, serta cara bagaimana agar dibaiyah atau barjanzy ini terus bisa dilestarikan.

c. Melestarikan Tradisi Dibaiyah

Menurut Hamidulloh Ibda (2012) yang menulis artikel di NU Online dengan judul "Melestarikan Tradisi Barzanji", menyatakan bahwa selain dilakukan pada bulan Maulid, tradisi barzanji juga dilakukan kaum muslim pada setiap moment penting seperti pengajian, tasyakuran pernikahan, kelahiran anak, menjelang keberangkatan haji dan sebagainya.Barjanjen, merupakan tradisi yang dilakukan sejak dulu, terutama bagi umat Islam warga Nahdliyyin (warga NU).Mereka membacanya pada tiap malam Jumat dan upacara lainnya.Bahkan, pada sebagian besar pesantren di Jawa Tengah, barjanjen menjadi kegiatan wajib.

Di Indonesia, peringatan Maulid Nabi sepertinya sudah melembaga, bahkan ditetapkan sebagai hari libur nasional. Setiap memasuki Rabi'ul Awal, berbagai ormas Islam, masjid, musholla, institusi pendidikan, dan majelis taklim bersiap memperingatinya dengan beragam cara dan acara; dari sekadar menggelar pengajian, dialog keagamaan, bakti sosial, hingga ritual-ritual yang sarat tradisi (lokal). 
Di antaranya adalah: Manyanggar Banua, Mapanretasi di Pagatan, Ba'ayun Mulud (Ma'ayun anak) di Kab. Tapin, Kalimantan Selatan. Sekaten, di Keraton Yogyakarta dan Surakarta, Gerebeg Mulud di Demak, Panjang Jimat di Kasultanan Cirebon, Mandi Barokah di Cikelet Garut, dan sebagainya.

Tradisi barzanji, seharusnya menjadi spirit beragama bagi kaum muslim. Idealnya, barzanji bukan hanya sebagai rutinitas saja.Esensi Maulid Nabi adalah spirit sejarah dan penyegaran ketokohan Nabi sebagai satu-satunya idola teladan yang seluruh ajarannya harus dibumikan.Figur idola menjadi miniatur dari idealisme,kristalisasidari berbagaifalsafah hidup yang diyakini.Teladan sejarah dan penyegaran ketokohan itu dapat dilakukan kapan pun, termasuk di bulan Rabi'ul Awal.

Berpijak dari itu, sudah saanya umat Islam melestarikan tradisi tersebut. Pasalnya, dewasa ini banyak orang islam yang beragama setengah hati, atau dengan kata lain "Islam KTP”. Secara logika, daripada melestarikan budaya barat, lebih baik melestarikan budaya islam sendiri, sebagai suatu wujud ketaatan hamba dengan Tuhannya.Jadi, melihat tradisi barjanjen yang hanya menjadi rutinitas di bulan maulid, penulis lebih sepakat dan mendukung untuk melestarikan budaya barjanjen yang harus dijalankan setiap waktu, kapan pun dan dimana pun.Hal itu termasuk wujud bukti kecintaan kita sebagai umat Nabi Muhammad SAW.

Meskipun momen bulan maulid terasa sudah lewat, namun melestarikan tradisi barzanji merupakan sebuah keniscayaan bagi warga NU.Menjadi umat yang cinta Nabi Muhammad SAW, sudah saatnya membumikan tradisi ini sejak dini.Mau tidak mau, barzanji merupakan ciri khas warga NU.Jadi, melestarikan tradisi barzanji adalah harga mati.

Jama'ah diba'iyah di Kelurahan Paju terdiri dari jama'ah ibu-ibu rumah tangga dari berbagai kalangan orang bawah maupun atas, dan mempunyai berbagai profesi sendiri-sendiri, seperti: petani, guru, pedagang, penjahit dan ibu rumah tangga. Jama'ah ini berdiri karena adanya kesadaran dari masing-masing individu untuk melestarikan kegiatan diba'iyah, sehingga kegiatan diba'iyah tidak punah, karena di era modern ini kegiatan ini hampir punah karena tidak adanya peminat dari anak-anak generasi muda.

Berdasarkan hasil penelitian yang penulis lakukan di kelurahan paju bahwasanya kegiatan tersebut berasal dari inisiatif seorang kiai yang pernah menuntut ilmu agama dan 
dijarkan pada ibu-ibu jama'ah yasin dan tahlil untuk melestarikan kegiatan dibaiyah/berjanji tersebut, sehingga apabila diwarga masyarakat ada kegiatan mauludan, jemuk manten ( srokalan, sepasaran bayi, selapanan, piton-piton, setahunan, aqiqahan dan lain-lain bisa mendatangkan kelompok ini.

Dari penjelasan dibaiyah tersebut bahwa kegiatn dibaiyah adalah riwayat hidup yang berhubungan dengan seseorang tokoh ulama masyarakat yang menjadi suri tauladan, baik mengenai silsilah, akhlaq keramahan dan sebagainya. Berdasarkan pengalaman diatas, hal ini dimasyarakat dipergunakan sebagai sarana untuk berdakwah.

Dalam kegiatan tersebut diharapkan mampu menumbhkan kesadaran warga setempat untuk selalu mendekatkan diri kepada Allah SWT, dengan berusaha tetap menjalankan perintahperintahnya dan menjauhi larangan-larangannya. Adapun tujuan dibaiyah/berjanji adalah untuk mendekatkan diri kepada Allah SWT, melalui tawasul terhadap para nabi dan para kekasih Allah SWT, agar mendapatkan keberkahan para auliya serta untuk memuliakan dan mencintai dzuriyah Rasulullah SAW Ahlul bait atau keluarga Rasulullah SAW sehingga tetap terprlihara kesuciannya.

Berdasarkan tujuan tersebut, dengan keyakinan bahwa melakukan kegiatan amaliyah dibaiyah atau berjanji dapat mendapatkan kebaikan tersendiri, baik kebaikan itu dirasakan oleh keluarga-keluarga yang telah meninggal maupun sesame manusia yang masih hidup serta adanya respon tanggapan dari masyarakat dan penerimaan yang baik oleh masyarakat kelurahan paju. Kegiatan dibaiyah merupakan kegiatan dalam rangka mengagungkan nama Allah SWT dengan cara bertawasul melalui kekasihnya. Hal ini bertujuan agar kita selalu bertawasul pada kekasih Allah SWT sebagai perantara mendekatkan diri kepada Allah SWT, disamping itu juga bahwa dibaiyah adalah suatu ibadah tambahan yang dapat menghibur kepada masyarakat secara batiniyah, dan merupakan suatu sarana pendidikan spiritual yang pada akhirnya membawa efek positif untuk selalu melatih kita untuk mendekatkan kepada Allah SWT.

Pertemuan warga diba'iyah biasanya dilakukan pada tanggal 12 Rabiul Awwal untuk memperingati kelahiran nabi Muhammad SAW. Kegiatan ini juga dilakukan sebagai kegiatan rutinan mingguan, kegiatan rutinan ini dilaksanakan oleh warga Kelurahan Paju untuk menambah kecintaan terhadap nabi Muhammad SAW dan menambah jalinan silaturahim yang erat antar warga sehingga terjadi kedamaian dan kenyamanan dalam lingkungan.Tidak hanya itu 
pertemuan diba'an ini juga dilakukan ketika ada hajatan dari anggota atau warga masyarakat Kelurahan Paju seperti acara sepasaran bayi, selapan, akikoh dan sebainya.

Untuk kegiatan rutinan mingguan, diba'iyah dilaksanakan di rumah-rumah anggota jama'ah diba' secara bergantian seperti halnya kegiatan rutinan jama'ah ibu-ibu yasinan pada saat ini. Biasanya kegiatan rutinan ini dilakukan setiap malam jum'at karena malam jum'at malam yang utama dari malam-malam yang lain dalam satu minggu. Dengan diadakannya kegiatan diba'an ini jalinan silaturahim warga Kelurahan Paju semakin erat dan dapat menambah ketenangan jiwa dalam kehidupan sehari-hari. Karena dalam setiap kali pertemuan untuk melaksanakan kegiatan diba'iyah, ketika baru datang di tempat kegiatan maupun mau pulang selalu ada salam bersalaman antara warga satu dengan warga yang lain, selain itu ketika kegiatan diba'iyah dalam suatu hajatan ada yang mengisi tausiah sehingga warga menjadi lebih memahami ilmu-ilmu agama.

\section{Kesimpulan}

Berdasarkan hasil penelitian tentang"Peran Majlis Diba'iyah dalam Membina Silaturrahim Masyarakat di Kelurahan Paju Kecamatan Ponorogo Kabupaten Ponorogo", dapat disimpulkan bahwa, Adanya kegiatan diba'iyah ini dapat menambah jalinan silaturahim warga Kelurahan Paju semakin erat, hal ini dikarenakan dengan diadakannya kegiatan diba'iyah masyarakat meluangkan waktu untuk berkumpul dengan tetangganya sehingga terjalinlah komunikasi yang erat antar warga. Mereka saling menyapa, saling berjabatangan ketika baru datang maupun ketika mau pulang dari kegiatan diba'iyah. Kendala dalam melaksanakan dib'an di Kelurahan Paju yaitu: kurangnya minat dari warga sehingga kegiatan dib'iyah tidak bisa berjalan dengan rutin, selain itu dengan minimnya generasi penerus yang bisa vokal sehingga kegiatan diba'iyah sulit berjalan pada setiap minggunya. Kurangnya dukungan dari sesepuh untuk pembinaan generasi muda sehingga lambat laun kegiatan diba'iyah bisa pudar. Hal lain yang menjadi kendala adalah alat untuk mengiringi dibaiyah seperti kompang dan lainyya sangat kurang, ada namun sudah tak layak pakai lagi.

\section{Daftar Pustaka}

Astrid, Susanto, (1997) Komunikasi Dalam Teori dan Praktek Bandung : Bina Cipta.. 
Aziz, M. Ali,(2004). Ilmu Dakwah (Jakarta : Kencana.

Bakhtiar, Wardi, (19990. Metode Penelitian Dakwah, Jakarta: Logos Wacana.

Cangara, Hafied, (1998). Pengantar Ilmu Komunikasi, Jakarta : PT. Raja Grafindo Persada.

Misbahuddin, M. (2018). Pembangunan Budaya Dalam Masa Islam Awal. Al-Adabiya: Jurnal Kebudayaan Dan Keagamaan, 13(02), 332-347. https://doi.org/10.37680/adabiya.v13i02.29

Moleong, Lexi J., (2006) Metode penelitian Kualitatif, Bandung: Remaja Rosda Karya.

Munir, M dan Wahyu Ilahi, (2006). Managemen Dakwah, Jakarta : Kencana.

Nazir, Moh., (1998). Metode Penelitian, Jakarta:Ghalia Indonesia..

Sahfutra, S. (2019). Konflik dan Bina Damai Masyarakat Multirelijius: Studi Masyarakat Turgo Lereng Merapi Yogyakarta. MUHARRIK: Jurnal Dakwah Dan Sosial, 2 (2), 7197. https://doi.org/10.5281/zenodo.3540507

Suprayogo, Imam, (2001) Metode Penelitian Sosial Agama Bandung: Remaja Rosda Karya. Widjaja, A.W, (1986). Komunikasi dan Hubungan Masyarakat, Jakarta : Bima Aksara. Yafi, Ali, (1992). Dakwah dalam Al Qur'an dan As-Sunah Jakarta : Makalah Seminar. 